\title{
Galvanic Corrosion of Ductile Cast Iron Coupled with Different Alloys in Synthetic Domestic Waste Water
}

\author{
CRISTIAN SAVIN ${ }^{1}$, CARMEN NEJ NERU ${ }^{1 *}$, MANUELA CRISTINA PERJ U1,2, COSTICA BEJ INARIU1*, DIANA BURDUHOS-NERGIS ${ }^{1}$, \\ ANDREI VICTOR SANDU ${ }^{1,2,3}$ \\ ${ }^{1}$ Gheorghe Asachi Technical University of Iasi, Faculty of Materials Science and Engineering, 67 D. Mangeron Str., 700050 Iasi, \\ Romania \\ ${ }^{2}$ Center of Excellence Geopolymer and Green Technology (CEGeoGTech), School of Materials Engineering, Universiti Malaysia \\ Perlis (UniMAP), Perlis, Malaysia. \\ ${ }^{3}$ Romanian Inventors Forum, 3 Sf. P. Movila Str., 700089 Iasi, Romania
}

\begin{abstract}
Waste water is an aggressive environment for transport pumps to treatment plants. The pumps used are generally, immersion pumps and are made of various elements like, rotor, stator, housing, screws, flanges, springs, seals, etc. The construction elements of the pumps are made of various metallic materials, such as nodular castiron, gray castiron, low alloy steel, stainless steel, aluminum, bronze, brass, copper, etc. When immersed in waste water, the metals form galvanic series. The paper presents the galvanic corrosion analysis of the above-mentioned metals in case the corrosive environment is waste water with various compositions.
\end{abstract}

Keywords: galvanic corrosion, nodular graphite cast iron, wastewater, galvanic coupler

The populated residential areas represent importantand grave sources of water quality deterioration. The wastewater is first collected in a compact pumping station -such as a plastic sump -and is then pumped by a wastewater pump to a gravity sewer or to another pumping station. There are certain locations where it is possible to convey sewage by gravity to a central treatment facility or storm water is conveyed up to disposal point entirely by gravity. Whereas, in case of large area being served with flat ground, localities at lower elevation or widely undulating topography it may be essential to employ pumping station for conveyance of sewage to central treatment plant. Sewage and storm water is required to be lifted up from a lower level to a higher level at various places in a sew erages system.

Pumping stations are often required for pumping of untreated domestic wastewater, storm water, combined domestic wastewater and storm water, sludge at a wastewater treatment plant, and treated domestic wastewater. Pumping of sewage is also generally required at the sewage treatment plant.

Several types of pumps are used in the sewerage system for pumping of sewage, sewage sludge, grit matter, etc. as radial-flow centrifugal pumps, axial-flow and mixedflow centrifugal pumps, diaphragm pumps, rotary screw pumps or pneumatic ejectors.

For pumping of water using radial-flow centrifugals and axial-flow and mixed-flow centrifugal type pumps normally bronze impellers, bronze or steel bearings, stainless or carbon steel shafts, and cast iron housing is used. For domestic wastewater pumping using radial-flow centrifugals and axial-flow and mixed-flow centrifugal type pumps similar material is used except that they are often made from cast iron, ductile cast iron or stainless steel impellers. Pumping of sewage is different than common water pumping due to polluted nature of the wastewater containing suspended solids and floating solids, which may clog the pumps. The dissolved organic and inorganic matter present in the sewage may chemically react with the pump and pipe material and can cause corrosion. Domestic wastewater consists of relatively weak solutions of non aggressive contaminant chemicals. The types and concentrations of contaminants in raw wastewater from domestic sources are fats, oils, greases, soaps, organic matter, dirt, human waste, food waste and anorganic compounds.

From a corrosion perspective, the sewage is no more corrosive than ordinary water, i.e., water that presents a $\mathrm{pH}$ near the neutrality. Wastewater is aerated in most parts of the wastewater system, at least where the biological reactions do not consume all the dissolved oxygen and produces much more corrosive conditions for many metals. The most common chemical contaminants in domestic wastewater are chlorides, nitrogen compounds and a wide variety of organic compounds. Sulfate and phosphate ions are present. The $\mathrm{pH}$ of domestic wastewater typically is between 6 and 7 , running slightly on the alkaline side of neutral where there is higher use of soaps and household cleansing materials, most of which are mildlyalkaline to increase their detergent effectiveness. Used water from manufacturing plants and factories can have a wider range of contaminants - some of which may significantly affect the corrosiveness of the wastewater. Accidentally, wastewaters can achieve low pH (acidic waters) or high $\mathrm{pH}$ (alkaline waters) which brings a corrosion accentuation [1-6].

Carbon steel and ductile cast iron both corrode slowly in aerated wastewaters. Corrosion rates in the normal aerated wastewater depend on the amount of aeration and to a lesser degree on the temperature. They seldom exceed $0.25 \mathrm{~mm} / \mathrm{y}$. This is relatively slow, but is high enough that carbon steel requires continual maintenance to achieve the long service life normally expected from pipes and other wastewater equipment, especially inside wastewater treatment plants. Corrosion rates of carbon steel and cast iron in wastewater can be accelerated 5 to 10 fold by local acidic conditions produced by

*email: Nejnerucarmen@yahoo.com; costica.bejinariu@tuiasi.ro 
microbiological action or by accidentally contaminations. Furthermore, pipes and other structure made from carbon steel and ductile cast iron can be externally corroded by the surrounding soil. In some situations it is likely that they will be in contact with more traditional materials as mixed systems where galvanic forces can interfere with the corrosion resistance of the individual metals adding a supplementary corrosiveness [7-21].

When a metal is immersed in a conducting liquid it takes up an electrode potential (also known as the corrosion potential). This is determined by the equilibrium between the anodic and cathode reactions occurring on the surface and it is usually measured with reference to a standard electrode such as the saturated calomel electrode (SCE) [1-3].

Galvanic corrosion is an electrochemical process in which one metal corrodes preferentially when is in electrical contact with a different type of metal and both metals are immersed in an electrolyte [1-6]. When two or more different type of metal come into contact in the presence of an electrolyte a galvanic couple is set up as different metals have different electrode potentials. The electrolyte provides a means for ion migration whereby metallic ions can move from the anode to the cathode. This leads to the anodic metal corroding more quickly than it otherwise would; the corrosion of the cathode metal is retarded even to the point of stopping. The presence of electrolyte and a conducting path between the metals may cause corrosion where otherwise neither metal alone would have corroded. Even a single type of metal may corrode galvanic ally if the electrolyte varies in composition, forming a concentration cell.

The reactions which occur are similar to those that occur on single, uncoupled metal, but the corrosion rate is appreciable increased. The effect of coupling the two metals together increases the corrosion rate of the anode and reduces or even suppresses corrosion of the cathode.

When a metal is corroding two processes occur. One is the dissolution of metal at the anode. In the case of ferrous alloys Fe is dissolving metal, as:

$$
\mathrm{Fe} \rightarrow \mathrm{Fe}_{2}++2 \mathrm{e}-
$$

This must be balanced by a cathode reaction. Most practical cases of bimetallic corrosion occur in solutions containing dissolved oxygen and in most neutral and alkaline liquids the primary cathode reaction is the reduction of dissolved oxygen:

$$
\mathrm{O}_{2}+2 \mathrm{H}_{2} \mathrm{O}+4 \mathrm{e}-\rightarrow 4 \mathrm{OH}-
$$

In acidic liquids the cathode reaction is often the reduction of hydrogen ions to hydrogen gas:

$$
2 \mathrm{H}++2 \mathrm{e}-\rightarrow \mathrm{H}_{2}(\mathrm{~g})
$$

In deaerated environments other cathode reactions can occur, as reduction of partially oxidized sulphureous species. Under uncoupled corrosion the anodic and cathodic reactions occur at small, local areas on the metal. In a bimetallic couple the cathodic reaction is more, or totally, on the electropositive member of the couple and the anodic reaction is mostly, or totally, on the electronegative component of the couple.

Many factors can influence the corrosion in a coupled pair of different metals, i.e. couple potential $\left(E_{\text {couple }}\right)$ and current density of couple $\left(\mathrm{j}_{\text {couple }}\right)$. Among these on can evidences: the difference in electrode potentials of the individual partner of the couple, the quality of the electrical connection between the metals, the conductivity of the electrolyte, area ratio of the two electrodes, their configuration (i.e., the distance between the dissimilar metals), aeration, metallurgical composition and stifling effects due to the diminishing rate of diffusion of oxygen through the electrolyte and through films of corrosion product to cathode regions. Similar studies were performed on different type of materials, according to their use [2132].

This investigation was aimed to study the effect of coupling the ductile cast iron (nodular cast iron) with different alloys in three type of synthetic wastewater.

\section{Experimental part}

The ductile cast iron was coupled cu different alloys wherewith can come into contact in pumping stations. The compositions of the ductile cast iron and those of the other alloys used in this study are presented in table 1. These compositions were determined by optical emission

\begin{tabular}{|c|c|c|}
\hline Alloy & Abr. & Concentration, \% \\
\hline Ductile cast iron & DCI & $\begin{array}{l}\text { Fe-78.1; C- } 4.5 ; \mathrm{Si}-2.28 ; \mathrm{Ni}-0.12 ; \mathrm{W}-2.29 ; \mathrm{P}-0.05 \\
\mathrm{Cr}-0.02 ; \mathrm{Pb}-0.350 ; \mathrm{Mo}-0.200 ; \mathrm{Mn}-0.09 ; \mathrm{S}-0.150\end{array}$ \\
\hline Cast metal care & $\mathrm{CI}$ & Fe-92.78; C-3.97:S-2.87; Mn- $0.25 ; \mathrm{P}-0.06 ; \mathrm{S}-0.07 ;$ other- 1.02 \\
\hline $\begin{array}{l}\text { High strength low-alloyed } \\
\text { steel }\end{array}$ & HSLA & Fe-97.1;C-0.16; Si-0.21;Mn- $1.34 ; \mathrm{P}-0.02 ; \mathrm{S}-0.08 ;$ other- 1.19 \\
\hline Bronze & BRZ & $\mathrm{Cu}-85,62 ; \mathrm{Sn}-11,2 ; \mathrm{Pb} 1,0 ; \mathrm{Zn}-1,39 ;$ other- 0.79 \\
\hline Brass & BRS & $\begin{array}{l}\mathrm{Cu}-62,8 ; \mathrm{Zn}-26,8 ; \mathrm{Al}-6,03 ; \mathrm{Pb}-0,91 ; \mathrm{Sn}-0,57 ; \mathrm{Fe}-0,97 ; \mathrm{Ni}-0,46 ; \mathrm{Co}-0,46 ; \text { other } \\
-1.46\end{array}$ \\
\hline Stainless steel & SS & Fe-71.58; Cr-17.12; Ni-9.03; Ti-0.02; C-0.05; Si-0.45; Mn-0.0; P-0.03; S-0.01 \\
\hline Aluminium & AL & $99.9 \%$ \\
\hline
\end{tabular}

Table 1

THECOMPOSITIONSOF THE USED ALLOYS

\begin{tabular}{|l|c|l|c|l|c|}
\hline Chemical Components & $\mathrm{mg} / 1$ & $\begin{array}{l}\text { Alimentary } \\
\text { Components }\end{array}$ & $\mathrm{Mg} / 1$ & Metal Traces & $\begin{array}{c}\mathrm{Mg} \\
1\end{array}$ \\
\hline $\mathrm{NH}{ }_{4} \mathrm{Cl}$ & 15 & Milk powder & 118 & $\mathrm{Cr}\left(\mathrm{NO}_{3}\right)_{3} .9 \mathrm{H}_{2} \mathrm{O}$ & 0.10 \\
\hline $\mathrm{CH}_{3} \mathrm{COONa} .3 \mathrm{H}_{2} \mathrm{O}$ & 142 & Yeast & 54 & $\mathrm{CuCl}_{2} .2 \mathrm{H}_{2} \mathrm{O}$ & 0.20 \\
\hline $\mathrm{MgSO}_{4} .7 \mathrm{H}_{2} \mathrm{O}$ & 32 & Starch & 122 & $\mathrm{MnCl}_{2}$ & 0.05 \\
\hline $\mathrm{CaHPO}_{4}$ & 20 & Soy oil & 15 & $\mathrm{NiSO}_{4} .7 \mathrm{H}_{2} \mathrm{O}$ & 0.08 \\
\hline $\mathrm{K}_{2} \mathrm{HPO}_{4} .3 \mathrm{H}_{2} \mathrm{O}$ & 56 & & & $\mathrm{PbCl}_{2}$ & 0.07 \\
\hline $\mathrm{FeSO}_{4} .7 \mathrm{H} 2 \mathrm{O}$ & 14 & & & & \\
\hline Urea & 98 & & & & \\
\hline Peptone & 15 & & & & \\
\hline
\end{tabular}

Table 2

BASIC COMPOSITION OF THE SYNTHETIC WASTEWATER (DWW-1) 
spectroscopy (Foundry-Master emission spectrometer, WAS Company).

Synthetic test waters were prepared according with the Boeije [7] studies concerning the mean composition of the settled water from the sewage of the municipal sewerages. The constituent selection of the synthetic solutions is based on the expected composition of domestic waters exhaust. Some changes were made in the Boeije composition, regarding the ratio between inorganic constituents especially. The composition of the basic synthetic wastewater, denoted DWW-1, is presented in table 2. The inorganic components are respondent for the corroding properties of the solution, while the alimentary components behave as corrosion inhibitor or protector. This solution has a $\mathrm{pH}$ closed to neutrality: $\mathrm{pH}=6.5$.

Towards analyze the $\mathrm{pH}$ influence regarding corrosion behavior, the $\mathrm{pH}$ of the base solution (DWW-1) was modified byadding hydrochloric acid and sodium hydroxide respectively. Thus were obtained the alternative solutions: DWW -2 , with $p H=3.0$, by titration of basic solution with $0.1 \mathrm{M} \mathrm{HCl}$ solution; DWW -3 , having a $\mathrm{pH}=11.0$, by titration of basic solution with $0.1 \mathrm{M} \mathrm{NaOH}$ solution.

To evaluate the galvanic corrosion parameters, galvanic potential - $E_{\text {couple }}$ and galvanic current $-j_{\text {couple }}$, the Evans method and a commercial potentiostat/gauvanostat were used. All measurements were performed with the VoltaLab 21 (PGP201) potentiostat (Radiometer Analytical SAS Fran(a), equipped with the acquisition and processing data software VoltaMaster 4 [33-37]. A special three electrodes electrochemical cell was used. This cell is presented in (fig.1). Ductile cast iron was mounted as work electrode, while the other materials were mounted as auxiliary electrode. A saturated calomel electrode (SCE) was used as a reference. All electrodes were realized as cylindrical disks ( $10 \mathrm{~mm}$ diameter and $2 \mathrm{~mm}$ thickness), and were screwed at cell connectors.

The free surface of the connector was covered with acrylic glass. In these conditions, all electrodes present the same surface: $2.76 \mathrm{~cm}^{2}$.

Each specimen was polished with SiC paper, gradually, down up 2000 grit specification, degreased with acetone, washed in distilled water, and maintained in working solution for a determined period of time, up to constant temperature. The measurements were performed in fresh natural aerated solutions at $23^{\circ} \mathrm{C}$.

The measurements were performed according to Evans method using the facilities offered by VoltaLab 21 potentiostat and VoltaMaster 4 acquisition software, using Evans test sequence (Coupled Corrosion - Evans) respectively. Briefly, an imposed currentis applied gradually to the two electrodes and the voltammetric curves are registered, namely: potential of the working electrode $E_{\text {wo }}$ versus current and potential of the auxiliary electrode $\left(E_{\text {aux }}\right)$ versus the same current.

Both potentials are measured versus reference electrode. The measurementstops when $E_{\text {work }}-E_{\text {aux }}$ potential sign reverses. The intersection of the two curves determine the corrosion current and mixed potential (named and rest potential). As an example, in figure 2 is illustrated a typical diagram for ductile cast iron-stainless steel couple in DWW1. To compare the data obtained in different situations, instead of the corrosion current (I) the corrosion current density $(j=1 / S)$ is calculated.

\section{Results and discussions}

Four or six successive measurements were performed for each pair of coupled alloys. The mixed potential and the couple current densities are presented in tables 3, 4 an
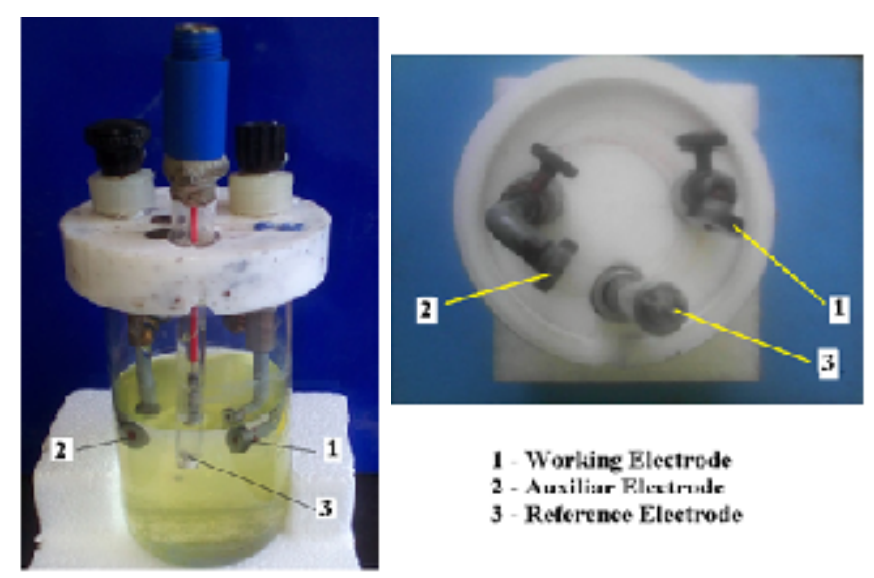

Fig.1. Three-electrodes electrochemical cell

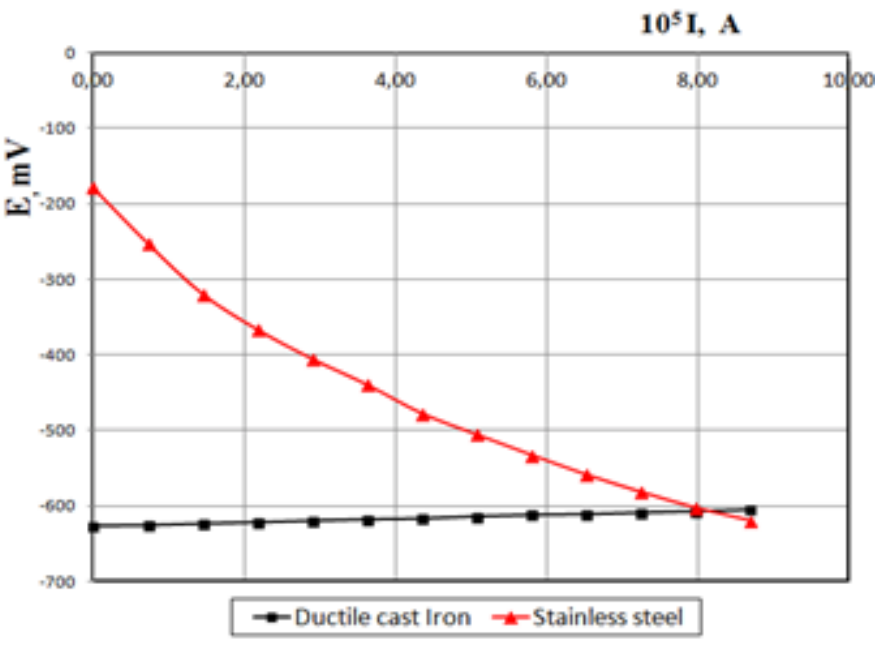

Fig.2. Evans curves for Ductile cast iron/Stainless steel pair in DWW-1 corrosion medium

5, dependent on corrosion medium and elapsed-time from the measurement starting. In all measurements the aria ratio of the anode and cathode were strictly equal with unity and the system configuration was unchanged, so that these parameters no influence actual results.

Very different results were obtained depending on nature of coupled alloys and corrosion medium $\mathrm{pH}$. Some conclusions are presented forwards.

In the case of Ductile Cast iron/Stainless steel couple, the corrosion potential for the couple increase slightly with immersion time in all three synthetic waters and tend to a constant value. In alkaline water the corrosion potential is moved towards more negative value. Current densities of the couple have little and constant values in quasi neutral waste water (DWW-1) and are of approximately eight times higher in acidic waters (DWW-2). In acidic water the couple current density decrease in time, due to the appreciable increase of the corrosion products layer athigh value of couple current. In alkaline waste water (DWW-3) the couple current density is of only two times higher than in neutral waters and increase with time.

The couple Ductile cast iron/Bronze behaves approximately likewise in the three corrosion media, the current density of couple being comprised between 60 and $80 \mu \mathrm{A} / \mathrm{cm}^{2}$, saving that in DWW-1 the current density decrease from $60 \mu \mathrm{A} / \mathrm{cm}^{2}$ till $45 \mu \mathrm{A} / \mathrm{cm}^{2}$ in $45 \mathrm{~min}$. The corrosion potential for couple also increase slightly in time, a more pronounced increase being evidenced in neutral water.

In all the three corrosion media, for Ductile cast iron/ Brass couple the current densities decrease with time immersion, the decrease being also more pronounced in DWW-1. In acidic and basic media the current densities 
Table 3

GALVANIC COUPLESIN DWW-1

\begin{tabular}{|c|c|c|c|c|c|c|}
\hline \multicolumn{7}{|c|}{ Ductile cast iron - Stainless steel } \\
\hline$\tau, \min$ & 5 & 10 & 15 & 20 & 25 & 30 \\
\hline $\mathrm{E}_{\text {couple, }} \mathrm{mV}$ & -591 & -598 & -603 & -605 & -607 & \\
\hline $\mathrm{J}_{\text {couple, }} \mu \mathrm{A} / \mathrm{cm}^{2}$ & 24 & 24 & 24 & 24 & 22 & \\
\hline \multicolumn{7}{|c|}{ Ductile cast iron - Bronze } \\
\hline$\tau, \min$ & 5 & 10 & 15 & 20 & 25 & 30 \\
\hline $\mathrm{E}_{\text {couple, }} \mathrm{mV}$ & -538 & -548 & -556 & -559 & -565 & -567 \\
\hline $\mathrm{J}_{\text {couple, }} \mu \mathrm{A} / \mathrm{cm}^{2}$ & 60 & 55 & 50 & 50 & 45 & 45 \\
\hline \multicolumn{7}{|c|}{ Ductile cast iron-Brass } \\
\hline$\tau, \min$ & 6 & 13 & 20 & 28 & 36 & \\
\hline $\mathrm{E}_{\text {couple, }}, \mathrm{mV}$ & -577 & -591 & -600 & -608 & -613 & \\
\hline $\mathrm{J}_{\text {couple, }} \mu \mathrm{A} / \mathrm{cm}^{2}$ & 70 & 65 & 60 & 55 & 55 & \\
\hline \multicolumn{7}{|c|}{ Ductile cast iron - High strength low alloyed steel } \\
\hline$\tau, \min$ & 16 & 20 & 23 & 26 & 31 & \\
\hline $\mathrm{E}_{\text {couple, }} \mathrm{mV}$ & -583 & -587 & -588 & -592 & -596 & \\
\hline $\mathrm{J}_{\text {couple, }} \mu \mathrm{A} / \mathrm{cm}^{2}$ & 20 & 20 & 24 & 24 & 22 & \\
\hline \multicolumn{7}{|c|}{$\frac{1}{\text { Ductile cast iron - Cast metal care }}$} \\
\hline$\tau, \min$ & 4 & 7 & 10 & 12 & 14 & 16 \\
\hline $\mathrm{E}_{\text {couple, }} \mathrm{mV}$ & -636 & -647 & -651 & -657 & -662 & -662 \\
\hline $\mathrm{J}_{\text {couple, }} \mu \mathrm{A} / \mathrm{cm}^{2}$ & 22 & 18 & 14 & 12 & 12 & 10 \\
\hline \multicolumn{7}{|c|}{ Ductile cast iron - Aluminium } \\
\hline$\tau, \min$ & 2 & 4 & 6 & 8 & & \\
\hline $\mathrm{E}_{\text {couple, }} \mathrm{mV}$ & -634 & -634 & -634 & -634 & & \\
\hline $\mathrm{J}_{\text {couple, }} \mu \mathrm{A} / \mathrm{cm}^{2}$ & 6 & 6 & 6 & 6 & & \\
\hline
\end{tabular}

are neighbor of $80-90 \mu \mathrm{A} / \mathrm{cm}^{2}$, while in neutral water the values decrease from 70 to $55 \mu \mathrm{A} / \mathrm{cm}^{2}$ in $35 \mathrm{~min}$. The corrosion potentials increase with immersion time. The decrease on current densities and the increase of the couple potentials can be explained by the decrease on corrosion intensity as a result of the surface coating with corrosion products, process assured by relative high values of the corrosion current.

The Ductile cast iron/High strength low alloyed steel coupling shows a similar behaviour as the Ductile Cast iron/Stainless steel couple in DWW-1, both for corrosion density and corrosion potential. In acidic media the current density is of four times lower than the for Ductile Castiron/ Stainless steel couple and decrease very fast with immersion time (from $70 \mu \mathrm{A} / \mathrm{cm}^{2}$ to $35 \mu \mathrm{A} / \mathrm{cm}^{2}$ after 12 $\min )$. This behavior indicate a fastness passivating of the Ductile castiron. In basic solution (DWW-3) the corrosion behavior is practically similar with coupling of Ductile cast iron with Stainless Steel and with High strength low alloyed steel.

The coupling of Ductile cast iron with Cast metal care is less unfavourable in the three corrosion media; in DWW-1 the corrosion density decrease rapidly from 22 to $10 \mu \mathrm{A} /$ $\mathrm{cm}^{2}$ (16 min), in DWW-2 the corrosion density increase from $20 \mu \mathrm{A} / \mathrm{cm}^{2}$ to $30 \mu \mathrm{A} / \mathrm{cm}^{2}$ (14 min) and in DWW-3, the corrosion density is practically equal with $6 \mu \mathrm{A} / \mathrm{cm}^{2}$ (the most advantageous couple). The increase of corrosion current in acidic media is probable due to the solubility of the corrosion products.

\begin{tabular}{|c|c|c|c|c|c|c|}
\hline \multicolumn{7}{|c|}{ Ductile cast iron - Stainless steel } \\
\hline$\tau, \min$ & 10 & 20 & 45 & 55 & 60 & 65 \\
\hline$E_{\text {couplo, }}, \mathrm{mV}$ & -573 & -580 & -589 & -589 & -587 & -589 \\
\hline $\mathrm{J}_{\text {couple, }} \mu \mathrm{A} / \mathrm{cm}^{2}$ & 205 & 205 & 196 & 190 & 190 & 180 \\
\hline \multicolumn{7}{|c|}{ Ductile cast iron-Bronze } \\
\hline$\tau, \min$ & 6 & 10 & 14 & 17 & 20 & 23 \\
\hline $\mathrm{E}_{\text {couplo, }} \mathrm{mV}$ & -598 & -599 & -601 & -604 & -604 & -605 \\
\hline $\mathrm{J}_{\text {couplo, }} \mu \mathrm{A} / \mathrm{cm}^{2}$ & 70 & 70 & 70 & 60 & 60 & 60 \\
\hline \multicolumn{7}{|c|}{ Ductile cast iron - Brass } \\
\hline$\tau, \min$ & 4 & 7 & 11 & 15 & 19 & \\
\hline $\mathrm{E}_{\text {couplo, }} \mathrm{mV}$ & -602 & -607 & -609 & -613 & -612 & \\
\hline $\mathrm{J}_{\text {couple, }} \mu \mathrm{A} / \mathrm{cm}^{2}$ & 90 & 80 & 80 & 70 & 80 & \\
\hline \multicolumn{7}{|c|}{ Ductile cast iron - High strength low alloyed steel } \\
\hline$\tau, \min$ & 2 & 4 & 6 & 8 & 10 & 12 \\
\hline $\mathrm{E}_{\text {couplo, }} \mathrm{mV}$ & -604 & -611 & -614 & -619 & -620 & -620 \\
\hline $\mathrm{J}_{\text {couplo, }} \mu \mathrm{A} / \mathrm{cm}^{2}$ & 70 & 50 & 40 & 30 & 30 & 35 \\
\hline \multicolumn{7}{|c|}{ Ductile cast iron - Cast metal care } \\
\hline$\tau, \min$ & 1 & 2 & 6 & 10 & 12 & 14 \\
\hline $\mathrm{E}_{\text {couplo, }} \mathrm{mV}$ & -608 & -610 & -614 & -616 & -617 & -618 \\
\hline $\mathrm{J}_{\text {couple, }} \mu \mathrm{A} / \mathrm{cm}^{2}$ & 20 & 25 & 32 & 30 & 30 & 30 \\
\hline \multicolumn{7}{|c|}{ Ductile cast iron - Aluminium } \\
\hline$\tau, \min$ & 3 & 6 & 9 & 12 & 14 & \\
\hline$E_{\text {couplo, }} \mathrm{mV}$ & -628 & -630 & -625 & -635 & -638 & \\
\hline $\mathrm{J}_{\text {couple, }} \mu \mathrm{A} / \mathrm{cm}^{2}$ & -35 & -35 & -20 & -30 & -27 & \\
\hline
\end{tabular}

Table 4

GALVANIC COUPLE IN DWW-2 


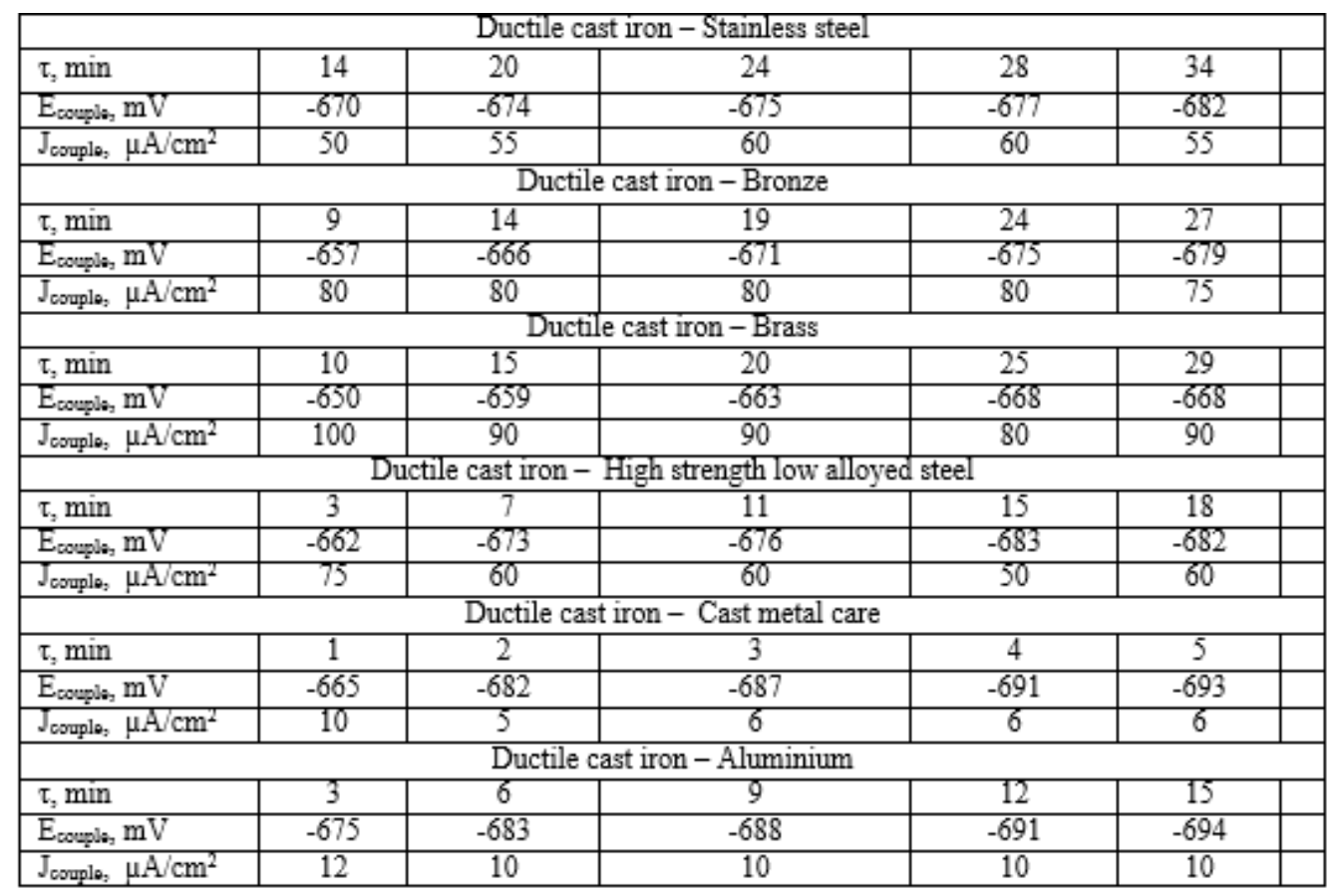

Table 5

GALVANIC COUPLE IN DWW-3
The Ductile cast iron/Aluminium couple shows a different behavior. Thus, in neutral and basic waters the current densities are very small and constant $\left(6 \mu \mathrm{A} / \mathrm{cm}^{2}\right.$ in DWW-1 and $10 \mu \mathrm{A} / \mathrm{cm}^{2}$ in DWW-2), this couple being harmless. In these couplings Aluminium is more noble partner and Ductile cast iron the less noble partner. In acidic medium (DWW-2) Ductile cast iron is more noble partner while Aluminium corrodes with enough high speed.

\section{Conclusions}

In the galvanic couples performed between Ductile cast iron (DCI) and other alloys as: Stainless steel (SS), Bronze (BRZ), Brass (BRS), High strength low alloyed steel (HSLA), Cast metal care (Cast iron) $(\mathrm{Cl})$ and Aluminium (AL), Ductile cast iron appear as corrodible material in synthetic domestic waste water neutral (DWW-1; $\mathrm{pH}=6.5$ ), acidic (DWW-2; $p H=3.0$ ) and basic (DWW-3; $p H=11.0)$. An exception is the couple Ductile cast iron/Aluminium in acidic waste water, where Aluminium appears as corrodible material.

Taking into consideration only the initial values (at $\mathrm{t}=0$ $\mathrm{min}$ ) of the couple current density, the following galvanic series can be determined:

Least noble - anodic Most noble - cathodic In DWW-1: DCl $<$ AQL $<$ HSLA $<\mathrm{Cl}<\mathrm{SS}<\mathrm{BRZ}<$ BRS In DWW-2: $\mathrm{AL}<\mathrm{DCl}<\mathrm{Cl}<\mathrm{HSLA}<\mathrm{BRZ}<\mathrm{BRS}<\mathrm{SS}$ In DWW-3: $\mathrm{DCl}<\mathrm{Cl}<\mathrm{AL}<\mathrm{SS}<\mathrm{HSLA}<\mathrm{BRZ}<\mathrm{BRS}$

Thus, the coupling of Ductile cast iron with Brass, Bronze or Stainless steel appear to be the most disadvantageous arrangement.

Acidic waste water enhances the galvanic corrosion of the analyzed of alloy pairs.

\section{References}

1.KELLY, R.G., SHOESMITH, D.W., BUCHHEIT, R.G., Electrochemical Techniques in Corrosion Science and Engineering, Marcel Dekker Inc, New York Basel, 2003.

2.PHILIPPE M., Corrosion Mechanisms in theory and practice, Marcel Dekker Inc., New York, 2002.

3.EVANS, U.R., An Introduction to Metallic Corrosion, 2nd ed. London: Arnold, 1972.

4.PAYER, J.H., and THOMPSON, N.G., DC Electrochemical Test Methods, Houston, Texas: NACE International Book Publications, 1998.
5.ROTHWELL N., and TULLMIN M., Machine and Systems Condition Monitoring Series: The Corrosion Monitoring Handbook, First Edition Oxford, UK: Coxmoor Publishing Company, 2000.

6.J ONES D.A., Principles and prevention of corrosion, 2nd ed. Prentice Hall, Newyork, 1996.

7.BOEIJE H., Chemical fate prediction for use in geo-referenced environmental exposure assessment, PhD. Thesis.Faculty of Agricultural and Applied Biological Sciences. Ghent University, p. 225, 1999.

8.AELENEI, D.M., Studiul coroziunii unor materiale dentare, PhD Thesis, Faculty of Materials Science and Engineering, Gh. Asachi Technical University of lasi, 2009.

9.BALTATU, S., VIZUREANU, P., MARECI, D., BURTAN, L.C., CHIRUTA, C., TRINCA, L.C., Materials And Corrosion-Werkstoffe Und Korrosion, 67, no. 12, 2016, p. 1314.

10.BALTATU, M.S., VIZUREANU, P., CIMPOESU, R., ABDULLAH, M.M.A., SANDU, A.V., Rev.Chim.(Bucharest), 67, no. 10, 2016, p. 2100.

11.NEJ NERU, C., PERJU, M.C., SANDU, A.V., AXINTE, M., QUARANTA, M., SANDU, I., COSTEA, M., ABDULLAH, M.M.A.B., Rev. Chim. (Bucharest), 67, no. 6, 2016, p. 1191.

12.PERJU, M.C., NEJ NERU, C., GALUSCA, D.G., a TEFANICA, R.G., Book Series: Proceedings of the International Conference ModTech, 2010, p. 455.

13.AXINTE, M., NEJ NERU, C., PERJU, M.C., SANDU, A.V., AELENEI, M.D., COSTEA, M., Rev.Chim.(Bucharest), 66, no. 11, 2015, p. 1846. 14.NEJ NERU, C., PERJU, M.C., SANDU, A.V., AXINTE, M., QUARANTA, M., SANDU, I., COSTEA, M., ABDULLAH, M.M.A., Rev.Chim.(Bucharest), 67, no. 6, 2016, p. 1191.

15.MINCIUNA, M.G., VIZUREANU, P., ACHITEI, D.C., SANDU, A.V., J ournal of Optoelectronics and Advanced Materials, 18, no. 7-8, 2016, p. 717-722.

16.TOTH, L., HARASZTI, F., KOVACS, T., European J ournal of Materials Science and Engineering, 3, no. 2, 2018, p. 98.

17.BUZAIANU, A., KARLSDOTTIR, S., RAGNARSDOTTIR, K., HARALDSDOTTIR, H., GUDLAUGSSON, S., MOTOIU, P., CSAKI, I., European Journal of Materials Science and Engineering, 2, no. 2-3, 2017, p. 63.

18.IOANNOU, P.D., NICA, P., PAUN, V., VIZUREANU, P., AGOP, M., Physica Scripta, 78, no. 6, 2008, Article Number: 065101

19.ACHITEI D.C., ABDULLAH, M.M.A.B., MINCIUNA, M.G., PERJU, M.C., European J ournal of Materials Science and Engineering, 2, no.4, 2017, p. 133 
20.GAVRILA, B.L., SUSAN, M., CHIRILA, E., BULANCEA, V., CRAUS, M.L., Optoelectronics And Advanced Materials-Rapid Communications, 6, no. 11-12, 2012, p. 1097.

21.MINCIUNA, M.G., VIZUREANU, P., ACHITEI, D.C.,GHIBAN, B., SANDU, A.V., MARECI, D., BALAN, A., Rev.Chim.(Bucharest), 65, no. 10, 2014, p 1138.

22.CIMPOESU, N., AXINTE, M., HANU, R.C., NEJ NERU, C., ACHITEI, D.C., STANCIU, S, J ournal Of Optoelectronics And Advanced Materials, 12, no. 8, 2010, p. 1772.

23.CIMPOESU, R.H., POMPILIAN, G.O., BACIU, C., CIMPOESU, N., NEJ NERU, C., AGOP, M., GURLUI, S., FOCSA, C., Optoelectronics And Advanced Materials-Rapid Communications, 4, no. 12, 2010, p. 2148. 24.RILA, E., SUSAN, M., GAVRILA, B.L., SANDU, A.V., Rev. Chim. (Bucharest), 64, no. 5, 2013, p. 482.

25.LUCA, C., IONESCU, S.D., CHIRILA, E., Mat. Plast., 47, no. 3, 2010, p. 370.

26.PERJU, M.C., GALUSCA, D.G., NEJ NERU, C., LARGEANU, A.E., Metalurgia International, 15, no. 11, 2010, p. 41.

27.MINCIUNA, M.G., VIZUREANU, P., ACHITEI, D.C., SANDU, A.V., BERBECARU, A., SANDU, I.G., J ournal of Optoelectronics and Advanced Materials, 18, no. 1-2, 2016, p.174,

28.VIZUREANU, P., PERJU, M.C., GALUSCA, D.G., NEJ NERU, C., AGOP, M., Metalurgia International, vol. XV, no. 12, 2010, p. 59.
29.CARABET, R.G., VIZUREANU, P., PERJU, M.C., ACHIPEI, D., Management of Technological Changes, Vol. 2, 2009, p. 33.

30.CIMPOESU, N., STANCIU, S., VIZUREANU, P., CIMPOESU, R., ACHITEI, D.C., IONITA, I., J ournal of Mining and Metallurgy Section BMetallurgy, 50, no. 1, 2014, p. 69.

31.CIUCA, I., BOLCU, A., STANESCU, M.M., ENVIRONMENTAL ENGINEERING AND MANAGEMENT J OURNAL, 16, no. 12, 2017, p. 2851. 32.BOLCU, A., DUMITRU, N., CIUCA, I., STANESCU, M.M., BOLCU, D., Mat.Plast., 54, no. 3, 2017, p. 423.

33.BOLCU, D., STANESCU, M.M., CIUCA, I., MIRITOIU, C.M., BOLCU, A., CIOCOIU, R., Mat.Plast., 54, no. 1, 2017, p. 1.

34.LUNGU, M., Coroziunea metalelor în mediul marin natural, PhD Thesis, Faculty of Chemical Engineering and Environmental Protection, Gh. Asachi Technical University of lasi, 2012.

35.MARECI, D., Comportarea electrochimicã a unor biomateriale, PhD Thesis, Faculty of Chemical Engineering and Environmental Protection,Gh. Asachi Technical University of lasi, 2004.

36.PUJAR, M.G., PARVATHAVARTHINI, N., DAYAL, R.K., and KHATAK, H.S., Int. J. Electrochem. Sci. 3, 2008, p. 44-55.

37.CARRILLO, I., VALDEZ, B., ZLATEY, R., STOYCHEVA, M., SCHORR, M., and CARRILLO, M., International J ournal of Corrosion, 2011, p.17.

Manuscript received: 21.10 .2018 